\title{
Ecosystem services and livelihoods in a changing climate: Understanding local adaptations in the Upper Koshi, Nepal
}

\author{
Laxmi D. Bhatta ${ }^{\mathrm{a}}$, Bob Eric Helmuth van Oort $^{\mathrm{b}}$, Nigel E. Stork ${ }^{\mathrm{c}}$ and Himlal Baral ${ }^{\mathrm{d}, *}$ \\ ${ }^{a}$ International Centre for Integrated Mountain Development ICIMOD, Post Box \# 3226, Kathmandu, Nepal; ${ }^{b}$ CICERO-Centre for \\ International Climate and Environmental Research-Oslo, P.B. 1129 Blindern, 0318 Oslo, Norway; ${ }^{c}$ Environmental Futures Research \\ Institute, Griffith School of Environment, Griffith University, 170 Kessels Road, Nathan, Brisbane, Queensland 4111, Australia; ${ }^{d}$ Centre \\ for International Forestry Research (CIFOR), P.O. Box 0113 BOCBD, Bogor 16000, Indonesia
}

(Submitted 9 March 2014; accepted 26 February 2015; edited by Berta Martin-Lopez)

\begin{abstract}
Mountain ecosystems are increasingly being affected by global environmental change, challenging the ubiquitous agroecosystem-based livelihoods of the people. This article uses participatory research methods to document and analyse (1) local and regional impacts of climate change on ecosystem services (ES) and livelihoods, and (2) the main current adaptation strategies of local peoples in the mountains of central Nepal. Major observed impacts include reduced precipitation and an irregular rainfall pattern, affecting paddy cultivation and winter crop production. Production is also affected by increased pest and pathogen prevalence. Other impacts include increased livestock disease and reduced forest regeneration. Our results confirm earlier findings of a decrease in the district's forest cover in past; however, substantial efforts in forest conservation and management at the local level have gradually increased forest cover in recent years. Despite the increased potential for forest ecosystem services, the availability of forest goods, in particular fuel wood, fodder and litter, have decreased because of a strict regulation on forest goods extraction. Additionally, new invasive species are colonising these forests, preventing regeneration of preferred and local forest vegetation in some areas and, as a result, the densities of tree crops are changing. Most users cope with these changes by short term, reactive solutions. However, a number of local adaptation strategies, such as changing both agricultural practices and water harvesting and management, are increasing efficiency in resource use. To increase the adaptive capacity of poor households, we suggest it is essential to incorporate climate change adaptations within the local planning process.
\end{abstract}

Keywords: climate change; adaptation; vulnerability assessment; cropping pattern; livelihoods; local adaptive capacity

\section{Introduction}

Ecosystem services, the benefits that humans obtain from ecosystems, are vital for rural livelihoods. Mountain agroecosystems not only provide agricultural commodities such as food and fibre, but also help protect biodiversity, water, carbon storage, and landscape amenity. However, recent environmental change coupled with other stressors is affecting the ability of mountain agro-ecosystems to continue to provide the quality and quantity of ecosystem services required for sustainable rural livelihoods (Gentle \& Maraseni 2012; Shrestha et al. 2012; Baral 2013). For this reason, the effects of changing climate on provision of ecosystem services is becoming an increasingly important area of investigation (MEA 2005; Shrestha et al. 2012; Baral 2013; Baral, Keenan, Sharma, et al. 2014). Ecosystem services are defined and classified in a variety of ways as has been extensively elaborated elsewhere (MEA 2005; Boyd \& Banzhaf 2007; Wallace 2007; Fisher \& Turner 2008, Fisher et al. 2009; TEEB 2009). Baral, Keenan, Stork, et al. (2014) outlined some influen- tial definitions that are frequently cited in environmental literature and associated classification systems.

Global climate change scenarios suggest that there will be considerable impacts on ecosystems and their associated ecosystem services with serious consequences for the livelihoods of communities, particularly in the most economically challenged parts of the world (IPCC 2001; Agrawal \& Perrin 2008; ICIMOD 2010; Van de Sand 2012). The Millennium Ecosystem Assessment (2005) recognises climate change as one of the major drivers of ecosystem change and argues that 'ecosystem degradation tends to harm rural populations more directly and has its more direct and severe impact on poor people'. Poor communities mostly rely on ecosystem services for their subsistence livelihoods and often have limited capacity to adapt to change, which makes them more vulnerable to climate change and other forms of changes (ICIMOD 2010). Limited access to resources, lack of diversification options for subsistence livelihoods, and lack of health and education, are some of the critical factors limiting the adaptive capacity of developing countries to climate change (Smit

\footnotetext{
*Corresponding author. Email: h.baral@cgiar.org
} 
et al. 2000; Boon \& Ahenkan 2012). The fourth assessment report of the Intergovernmental Panel on Climate Change (IPCC 2007a) projected a severe impact of climate change on mountain ecosystems, particularly because of their sensitivity to warming. The report also suggests that countries in Asia are likely to suffer from many extreme events, including glacier melts, flooding, and droughts, and will have severe impacts on natural resources and the environment.

Nepal is very vulnerable to the impacts of climate change because it is spread across many altitudes from $\approx 70 \mathrm{~m}$ a.s.l. to the tallest peak of the world, and this then threatens its economy which is so highly dependent on land-based industries in particular agriculture. Between 1982 and 1996, the average annual mean temperature has increased by $1.5^{\circ} \mathrm{C}$ with an average increase of $0.06^{\circ}$ C per annum (Shrestha et al. 2012) and, depending on which scenario is selected, recent projections indicate that this warming trend will accelerate, especially at higher elevations and during the summer (Xu et al. 2007; IPCC 2007a; Shrestha et al. 2012). Although there is considerable spatial and seasonal variation in the Himalayas in climate and phenology, rainfall, growing season, and ecosystems are changing in the Himalayas (Practical Action 2009; Shrestha et al. 2012). In general, precipitation is projected to decrease in the dry season and increase during the rest of the year for South Asia, while the reverse is true for Central Asia (IPCC 2007a).

The impacts of these changes are well documented for the mountains of Nepal (Gentle \& Maraseni 2012). For example, increasingly erratic rainfall, water scarcity and drought, flood, and soil erosion are affecting livelihoods of rural communities, primarily through their impact on the agriculture, forestry, and pasture resources (Cannon \& Muüller-Mahn 2010). Regmi (2007) reported a reduction in crop production in the year 2005 by $12.5 \%$ because of reduced early monsoon rainfall. While eastern Nepal received less rainfall in the same year, western Nepal suffered from a large flood which reduced crop production by $30 \%$ in the area (Regmi 2007).

The remoteness of mountain communities often means that they have limited communication and transportation, and as a result, mountain communities are marginalised and more vulnerable to environmental impacts. Mountain communities also have limited access to other resources, which means they have a relatively low capacity to adapt to these changes. Although many studies discuss impacts of climate change on rural livelihoods (e.g. Ellis 2000; Boon \& Ahenkan 2012), studies on the impacts on livelihoods in montane ecosystems are still very limited. In particular, in Nepal, the impacts of climate change on livelihoods need further understanding, both contextually and locally. This article attempts to fill some of this gap and is based on research carried out in such remote communities in the mountains of the Dolakha district in Nepal. It documents and analyses (1) major climate change impacts on agro-ecosystems and linked rural livelihoods and (2) the main current adaptation strategies used by local communities to cope up with these changes.

\subsection{Climate change adaptation in context of development and rural livelihoods in Nepal}

Adaptation to climate change in the context of development has been much discussed in recent years, with the discourse focussing primarily on whether adaptation is part and parcel of the development process in developing countries (IPCC 2001; Adger et al. 2003; Holmelin \& Aase 2013). It has been argued that it is impossible to separate adaptation from development (Cannon \& Muüller-Mahn 2010). Adaptation to climate change, as defined by the IPCC, constitutes an 'adjustment in natural or human systems in response to actual or expected climatic stimuli or their effects, which moderates harm or exploits beneficial opportunities' (IPCC 2001, 2007b). The term 'adaptation' in the context of climate change impact is now mostly considered to be synonymous with the 'capacity to cope with changes, reduce vulnerability, and improve livelihoods' (Agrawal 2009; Orlove \& O’Brien 2009). Adaptive capacity is contextual and varies among various segments of communities, countries, and societies, and individual, and changes over both time and scale.

Chambers and Conway (1992) describe livelihoods as a system comprising of assets, capabilities, and activities for a means of living. Different combinations of capacities and activities form different household level livelihoods strategies, which not only generate income but include many other elements, including social assets (Ellis 2000). The livelihood approach is further discussed by Hahn et al. (2009) who combine the IPCC vulnerability framework with livelihoods approach (Chambers \& Conway 1992; Scoones 1998). Livelihoods are considered sustainable when they can cope with and recover from such stresses and shocks and maintain or enhance their capabilities and assets both now and in the future, although not undermining the natural resource base (Carney 1998). This definition strongly argues for and supports enhancement of the adaptive capacity of rural communities to ensure sustainability of their livelihoods.

Rural communities are mostly dependent on ecosystem services such as water, forest products, grass, and fodder for livestock, fisheries, for their livelihoods, although the priority ecosystem services may vary depending on different interest groups (Paudyal et al. 2015). Paudyal et al. (2015) found that in Dolakha district, rural women's main concern is forests as a source for firewood, while men are more concerned about timber production. Recent changes in local and regional climate, however, coupled with other drivers are affecting the continuous or sufficient supply of many ecosystem services. Availability and supply of such services is in large part weather-dependent and may be seasonal. Evidence shows that communities that have been practising adaptation to various changes in these resources for a long time have developed management decisions to cope with these changes (Dovers 2009; Alexander et al. 2010; Berrang-Ford et al. 2011; van Oort et al. 2014). However, these adaptation measures and practices vary widely and are contextualised. In particular, in developing countries and rural communities, these practices need to be understood and documented when aiming for a 
broader and more effective policy development (IPCC, 2007a). The study presented here is part of the Himalayan Climate Change Adaptation Programme (HICAP, www.icimod.org/hicap), which links scenarios of climate change and hydrology to an assessment of vulnerability and adaptation, impacts on ecosystem services, food security, and gender issues in the Hindu Kush Himalayas. The HICAP project has a particular focus on local level impacts and adaptation linked to sustaining livelihoods.

\subsection{Ecosystem, livelihoods, and climate change in the research area}

Dolakha district is a mountainous district of Nepal, varying in altitude from 723 to $7134 \mathrm{~m}$ above sea level (see Figure 1). The district has a human development index (HDI: $1=$ best, $0=$ worst) of 0.450 , life expectancy at birth is 63.5 , human poverty index is 44.0 , and adult literacy is 51.10 , with an overall HDI ranking of 42 out of 75 districts in Nepal (UNDP 2004; CBS 2011). From 2001 to 2011, the population decreased by about $8.65 \%$ (CBS 2011).

Dolakha is considered to be one of the richest districts for natural resources in Nepal. Estimates of land cover vary from different sources but are roughly comparable with ongoing monitoring efforts aimed to improve the quality of these data (see, e.g., www.franepal.org for current forest cover assessments). Forest and shrubs cover $47-55 \%$ of the area, followed by agriculture $(\approx 26 \%)$ and pastureland $(\approx 13 \%)$, unproductive land (barren/snow covered: $\approx 12-19 \%$ ), and water bodies $(\approx 0.19 \%)$ (Charmakar 2010; CBS 2011). Agriculture is the main source of income with about $67 \%$ of the population directly involved, followed by small scale enterprises and businesses. In recent years, remittances from outside the country have increased. Rain-fed agriculture is dominant with limited irrigation facilities for major crops, such as rice,

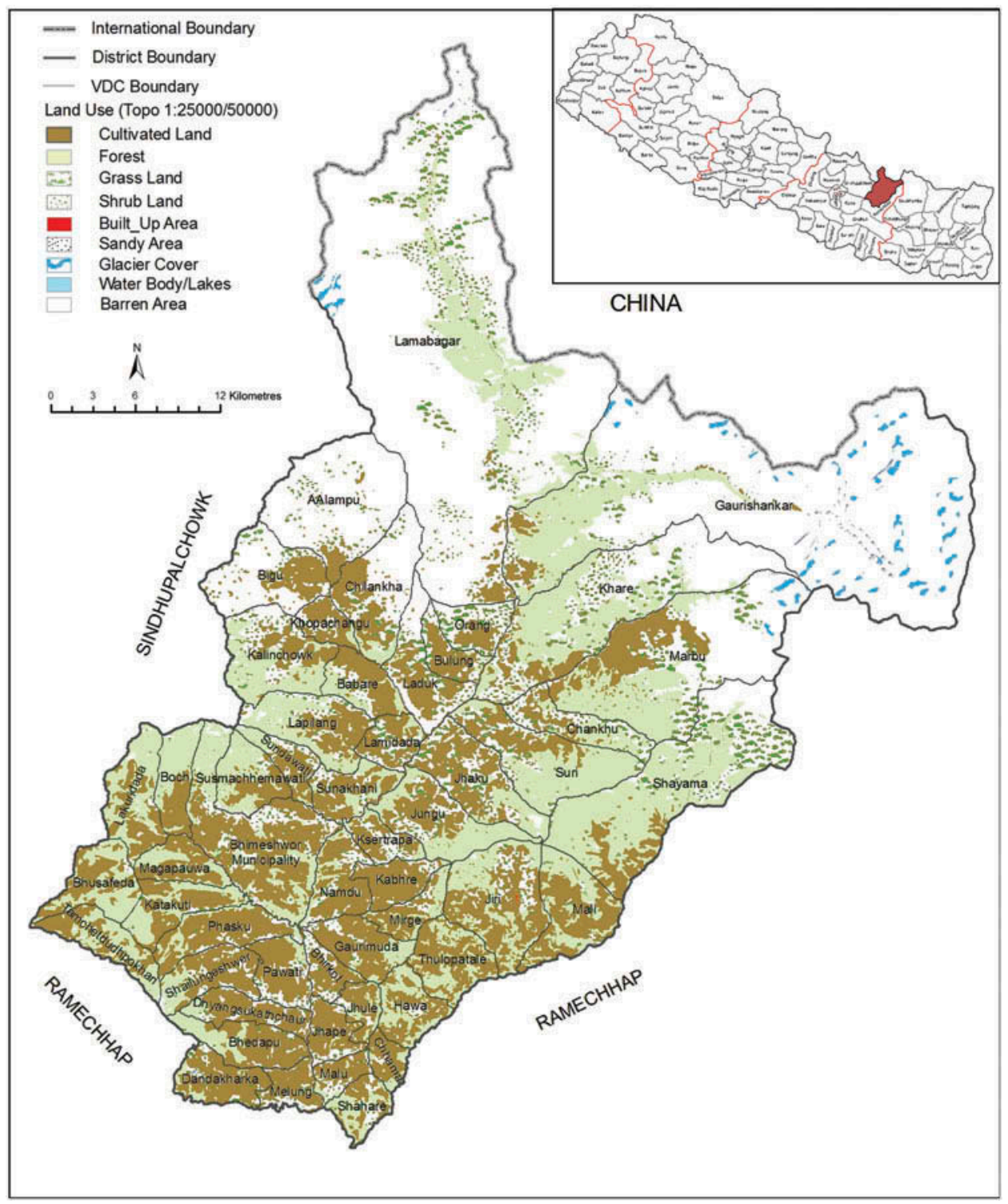

Figure 1. Map showing land uses in the study area, Dolakha district, and its location in Central Nepal (marked area in the inset figure). Figure adapted from (http://www.mofald.gov.np/). 
wheat, millet, maize, and potato. Besides agriculture, nontimber forest products (with possible added value through processing) are an important form of natural resource use (DFO 2012). Production of Nepali handmade paper and aromatic and essential oils are major forest-based enterprises providing additional income to local communities.

In recent years, agriculture- and forest interface-based livelihoods have been changing along with a change in the rainfall pattern and increased drought periods (Charmakar 2010). Reduced precipitation and an irregular rainfall pattern have directly adversely affected the highly rain-dependent paddy cultivation. In addition, increased impacts from various insects pests were noticed in rice, potato, and millet, reducing total production (Paudel 2013). For example, with prolonged drought, the incident of blight in potato is increasing. Similarly, with decrease in snowfall, caterpillar attack in Nepali alder (Alnus nepalensis) has increased. Charmakar (2010) also reported on the direct impact of prolonged drought and less rainfall on the reduced production and quality of winter grass (Gaultheria fragrantissima) used as a medicinal plant and an important source of cash income. There are a number of reasons behind the decrease in production, both in agriculture and forest crops. These include (1) changes in rainfall patterns, (2) longer periods of drought, (3) decrease in soil moisture, (4) increased crop intensity with increased use of chemical fertilizer and pesticides, and (5) consequential soil degradation. Importantly, forest cover in the region had decreased substantially between 1978 and 1994 (FAO 1999) but has increased since then due to the community forestry programme (Niraula et al. 2013; Paudyal et al. 2015). The issues described above provide the background for the current paper and the pressing need to understand how climate may impact on local agro-ecosystems and natural resources and how local communities are adapting to these changes.

\section{Methods}

Various tools have been developed to assess the sustainability of land use and livelihoods and to understand the role of stresses, risks, and vulnerability of communities to climate change. These include the Poverty and Vulnerability tool (PVAT) and the Vulnerability to Resilience framework (Marshall et al. 2009; Pasteur 2010; Macchi et al. 2011) and a number of participatory rural appraisal (PRA) techniques and tools (Chambers \& Conway 1992; Chambers 1994). The International Centre for Integrated Mountain Development (ICIMOD) developed a Vulnerability and Adaptive Capacity (VACA) Assessment tool, a refined version of the earlier PVAT. The ICIMOD developed VACA is based on theoretical framework on vulnerability as function of adaptive capacity, exposure, and sensitivity. In each dimensions of vulnerability, a number of indicators are used to assess their significance.

In this study, we used PRA tools such as community resource mapping, developing seasonal calendars for agricultural and forest products, and participatory rapid assessment of forest ecosystems and Focus Group Discussions (FGDs) to document local knowledge and perceptions of change. Five FGDs, typically consisting of 12 invited persons, were organised in parallel including (1) forest user groups, (2) water user groups, (3) women groups, (4) groups from the minority caste (mostly Tamang), and (5) groups from other castes (mostly Brahmin, chhetri). VACA surveys were carried out at household and community level throughout the Hindu Kush Himalayan region between 2011 and 2013, covering a total of 366 villages and 8048 households in four countries, 120 villages and 2311 households of these being in Nepal. For this article, we limited the VACA analysis to 385 households in the Dolakha district in Nepal, with a focus on local perceptions of the climate change impacts on community livelihoods, what local adaptation measures had been used to cope with these changes, and whether there were local social institutions to support such adaptation processes. To understand the significance of local contexts, the VACA analysis was complemented by five semi-structured focus group discussions and five key informant surveys in one ward within the Lakuridanda Village Development Committee (VDC) of the Dolakha district. Additionally, an ethnographic analysis was conducted through a questionnaire to all households located within the ward. The VACA survey was based on a random sampling design across seven representative districts and several villages in the Koshi river basin. In the VACA, the head of household, which in most cases was male, was the informant for questionnaire. However, if the head of household was not available, the next most senior person was interviewed.

Finally, historical meteorological data comprising daily and annual maximum and minimum temperature and precipitation data from the local meteorological station at Jiri were compared with local perceptions of change. This comparison provides an indication of how recent climatic changes, if any, have been experienced, what impacts are attributed to these, and what adaptation measures (if any) had been implemented. This approach 'validates' qualitative experiences with quantitative measurements.

Here, we use the Millennium Ecosystem Assessment (MEA 2005) definition of ecosystem services 'the benefits people obtain from ecosystems'. Community surveys indicate the ecosystem services that are recognised and prioritised at the local level as those that affect livelihoods. As such, we particularly consider provisioning services (products) from forests and agro-ecosystems, and water. Water has become a key issue in the research area and has multiple impacts, particularly on the production of forest and agriculture products. Changes in these services were covered through questions regarding perceptions of change in the VACA survey and the complementary focus group and key informant discussions.

\section{Result and discussion}

\subsection{Changes in climate and natural hazards}

\subsubsection{Changes in temperature}

Temperature data from the Jiri meteorological station over the period 1980-2010 show an increasing trend with an 
(a)

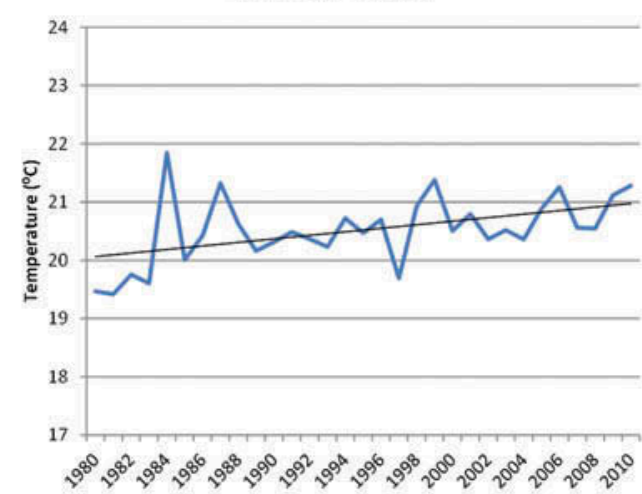

(b)

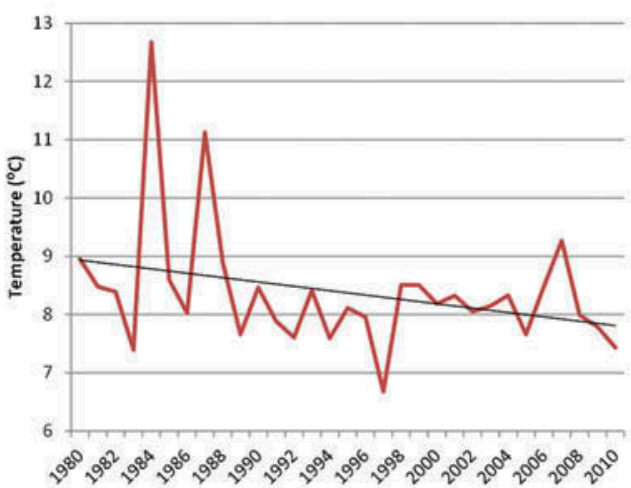

(c)

Seasonal Tmax

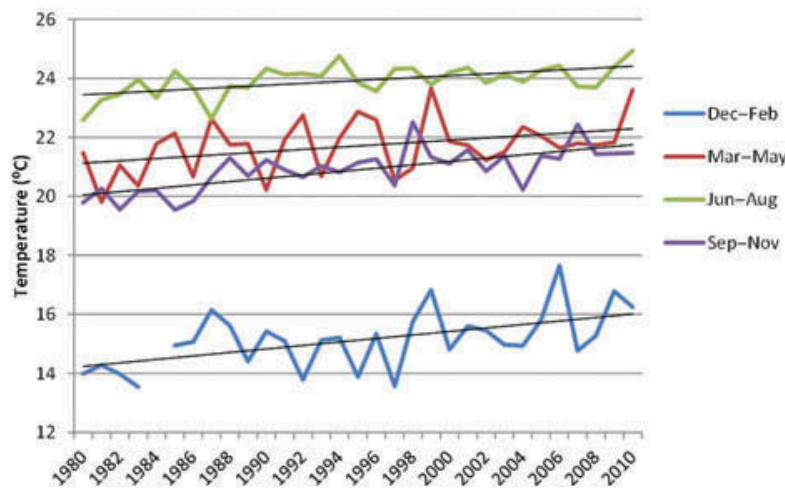

(d) Seasonal Tmin

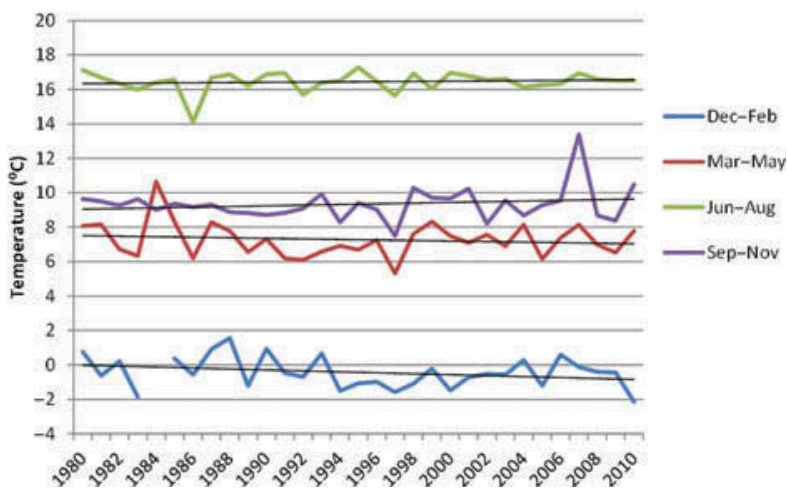

Figure 2. Variation in mean annual maximum and minimum temperatures 1980-2010. The figure shows variation in (a) annual average maximum temperatures; (b) annual average minimum temperatures; (c) seasonal average maximum temperatures, and (d) seasonal average minimum temperatures. While winters and autumn have become warmer on average, the variation in temperatures has increased: average maximum temperatures increased by up to $2^{\circ} \mathrm{C}$, but minimum temperatures decreased by $\sim 1^{\circ} \mathrm{C}$.

Source: Department of Hydrology and Meteorology, Government of Nepal.

increase of approximately $1^{\circ} \mathrm{C}$ in the annual average max temperature. Since there is also a decreasing trend of the same order of the annual average minimum temperature, this indicates that the annual average temperature has remained the same, but that temperature variation has increased (Figure 2a and b). A more detailed examination of the data (Figure $2 \mathrm{c}$ and $\mathrm{d}$ ) shows that the increasing trend of maximum temperatures is mainly due to increasing autumn and winter maximum temperatures of about $2^{\circ} \mathrm{C}$. Spring and summer average maximum temperatures increased as well, but only by about $1{ }^{\circ} \mathrm{C}$. The annual decrease of minimum temperatures is mainly due to a decrease of winter minimum temperatures, of about $1^{\circ} \mathrm{C}$.

Community perceptions and opinions, emanating from discussions on climate change directly and in the context of water availability and changes in phenology of some agriculture and forest crops, were in agreement with observed meteorological changes. Both indicate an increasing trend in maximum temperature. VACA data (Figure 3) indicate that 380 out of 385 household members answered positively on having noted a change in overall temperature, with most stating that the hot seasons have become hotter. Another perception was that colder seasons have become colder. Meteorological data shows that the average minimum temperatures in winter indeed have decreased by $\approx 1^{\circ} \mathrm{C}$. However, the maximum temperatures in winter have increased by $\approx 2^{\circ} \mathrm{C}$, so on average winters have in fact become warmer by $\approx 1^{\circ} \mathrm{C}$, which conflicts with the general perception. This misconception that winters have become colder (instead of warmer) may be due to people referring to night-time or daily minimum temperatures, which have indeed decreased over time, and not to the simultaneous increase of day-time or daily maximum

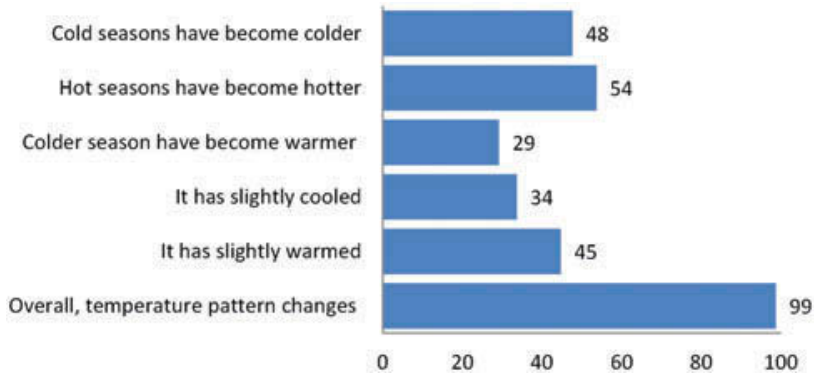

Figure 3. Top five perceived changes in temperature over 2003-2013 (in \%). 
Table 1. Changes in average rainfall patterns (in mm) from 1980 to 2010.

\begin{tabular}{lccccc}
\hline Range (in years) & Average annual & Winter (Dec-Feb) & Pre-monsoon (Mar-May) & Monsoon (Jun-Sep) & Post Monsoon (Oct-Nov) \\
\hline $1981-1990$ & 5.843 & 0.561 & 3.113 & 14.271 & 1.004 \\
$1991-2000$ & 6.597 & 0.527 & 3.512 & 16.035 & 1.453 \\
$2001-2010$ & 6.640 & 0.619 & 3.498 & 16.127 & 1.409 \\
\hline
\end{tabular}

Source: Department of Hydrology and Meteorology, Government of Nepal.

temperatures. Finally, people experienced climate as more variable than before, which was also reflected by the increasing difference between observed annual mean minimum and maximum temperatures (Figure $2 \mathrm{a}$ and $\mathrm{b}$ ).

\subsubsection{Changes in precipitation}

Table 1 shows the recorded change in precipitation for the last 30 years. The mean annual precipitation in Dolakha district from 1980 to 2010 is $2636 \mathrm{~mm}$, which is greater than the national average (Ministry of Environment 2010). The monsoon precipitation has seen a slight increase over time, especially from the ' 80 s to the 90 s'. The data also show that there has been an increase in the total annual precipitation in the first decade of the current century and that this was due to increased precipitation in the winter and the monsoon, while the pre- and post-monsoon periods have been dryer than in the '90s'.

Ninety-nine per cent of household members noted a change in precipitation over the last 10 years, agreeing with the climate measurement observations (Figure 4). There was also a perceived increase in annual precipitation, but with rain being more intense and spread over fewer days. Also, rainfall was said to be less in both summer (monsoon) and winter (dry period), and more erratic.

\subsection{Perceived impacts on livelihoods}

\subsubsection{Major natural hazards to livelihood resources}

Communities identified eight major hazards affecting the availability and quality of their livelihood resources (Table 2), including (ranked by severity of impact) erratic rainfall, increased pests and pathogens in agricultural crops, livestock disease, and drought (particularly affecting paddy crops and vegetables). The changes in climate increase the hazard and risks. Increases in temperature and decreases in snowfall increase the risk of pests and pathogen. Similarly, erratic rainfall and hailstorm destroys the crops and increase flood risks. Single events may also have an impact on the response. For example, in 2012, frost damaged potato crops in some of the potato growing areas, such as the Lakuridanda VDC. The severity of impact was perceived from minimal to very high, with some communities experiencing (and being impacted by) frost more than others.

\subsubsection{Forest products availability and change pattern}

Focus group discussions, and also timeline analyses, indicated a changing trend in both rainfall intensity and snowfall. Local communities observed that snowfall regulates the pests in forests. With decrease in snowfall and increasing temperature trend, more pests and diseases in tree crops were witnessed. Additionally, heavy rainfall in short bursts increases surface run-off with little increase in soil moisture. Whether related to the above or not, local observations suggested that seedling survival in regenerating forest has become very reduced in recent years with resulting lower cash income for commercially valuable nontimber forest species, such as Lokta (Daphne species).

With changes in climate and especially precipitation, community perceptions suggest that the productivity of forest crops has reduced, although these links need further scientific investigation. Perceptions and observations resulting from the analysis of focus group discussion are presented in Table 3. One of the participants of focus group discussion at Lakuridanda mentioned changes in tree phenology and altitudinal shift as follows:

I have noticed early flowering of some plants like Guras (Rhododendron species), Painyu (Prunus ceracoides). Similarly, plants like dudhilo (Ficus nemoralis), bhimsenpate (Buddleja asiatica) were previously only found on lower altitude but nowadays they are found at higher altitudes. It has been nearly 10 years since we have witnessed the change. (Dawa Lama, Lakuridanda FGD)

Although, forest cover in the area has been increasing at an average rate of $2.0 \%$ per year (Niraula et al. 2013), extraction of forest products from community forests is strictly regulated, hence restricting local community access to these new resources. The increasing spread of invasive weed species such as L. camara and Eupatorium reduce natural regeneration of local species, although the impacts of these invasives on forest regeneration needs further investigation.

\subsubsection{Effects on agriculture practices and production}

Perceived impacts of a changing climate on agriculture practices and production are key topics of discussion in communities. Local observations of a decrease in water availability attributed to increasing temperature and with reduced snowfall are considered to be major reasons for current changes in agricultural practices and cropping patterns. For example, communities in Lakuridanda VDC 


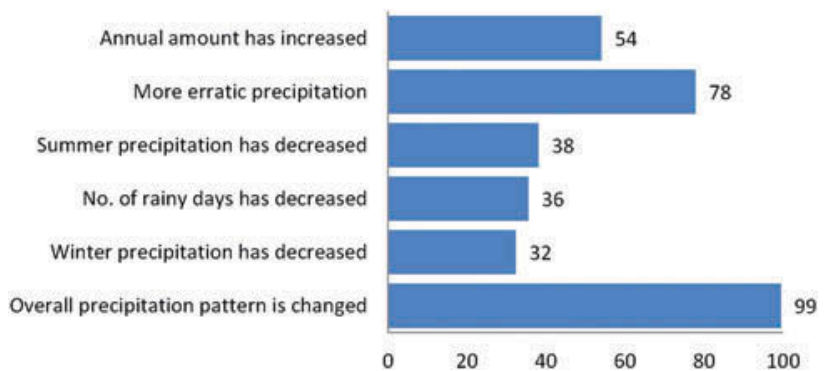

Figure 4. Top five perceived changes in rainfall pattern over 2003-2013 (in \%).

Table 2. Major climatic hazards to livelihoods resources and their perceived severity in percentage.

\begin{tabular}{llc}
\hline $\begin{array}{l}\text { Major } \\
\text { hazards }\end{array}$ & $\begin{array}{c}\text { Perceived severity of impact on } \\
\text { livelihoods resources }\end{array}$ & $\begin{array}{c}\text { Percentage of } \\
\text { respondents }\end{array}$ \\
\hline $\begin{array}{l}\text { Drought } \\
\text { Erratic } \\
\quad \text { rainfall }\end{array}$ & Medium to high & 13 \\
$\begin{array}{l}\text { Crop pests } \\
\text { Livestock }\end{array}$ & High & 54 \\
$\quad$ disease & Medium to high & 11 \\
Hailstorm & Minimum to medium & 42 \\
Frost & Medium (very high in 2012) & 29 \\
\hline
\end{tabular}

Source: Household Survey, 2012 Dolakha district Nepal.

used to cultivate wheat and paddy in downstream sites when there was sufficient water available. However, they now no longer cultivate paddy as there is insufficient available water, reflecting the observed reduction in rainfall over the last 10 years. Similarly, some of Tamang community members mentioned that production of wheat in winter is reduced because of increasing winter drought. Some of the participants of the local focus group discussion mentioned a $50 \%$ reduction in production of winter vegetables. These potential impacts of climate change on cropping patterns and reduced production are reflected in an increased market demand, resulting in an increased focus on cultivation of vegetable crops instead of cereal crops in an area that in fact may not be suited for this.

Potato is one of the major cash crops for many poor families, but its cultivation also may be at risk due to water shortage and heavy rainfall events. One of the key informants during the interview stated;

Before, due to the heavy snowfall and frost, the soil used to be moist throughout the year but nowadays soil has become drier causing difficulty even for potato cultivation. Moreover, in few years to come the possibility of water shortage has been sensed to increase such that the farmers are less hopeful for better cultivation (especially potatoes). Even during rainy season when the potato plants are big enough, they often get destroyed by heavy and erratic rainfall. (Key Informant, Lakuridanda VDC)

Livestock farming has been an important source of income for majority of population. There is a very famous saying in the village 'Oon bechi sun lagau' which literally means 'sell wool and wear gold', but now the situation has changed with the decline in sheep farming in the area. Rearing of sheep and Himalayan goat has drastically declined in recent years because of decreasing availability of grass/pasture for rearing. Farmers claim that the grass gets dry earlier or alternatively that there is a reduction in growth of grasses due to the drought.

The VACA analysis shows that there is a reported decrease in production of major cash and staple crops over the last 10 years. With a decrease in production of major crops, farmers have been introducing improved hybrid varieties of crops (see Figure 7). Data show that $7 \%$ of households considered use of hybrid seed as part of their adaptation strategy, as productivity from native varieties continued to decline.

\subsubsection{Change in water availability}

Reducing water availability appears to be the key issue impacting local livelihoods in the area. Members of the water management committees indicated in focus group discussions that many natural springs were drying up and that water availability has been reduced by $\approx 25 \%$. Key informants indicated that one of the reasons for drying up of water springs was the increase in areas of monoculture pine plantation. According to them, pine plantations were introduced about 25 years ago when there were many natural water springs. Many of the water springs within pine forests are now dry. Local communities perceived that pine trees absorb a lot of water, reducing the underground water level. Additionally, they mention the effects of increased surface water runoff because of the understory of pine needles. Other studies on this topic in forests in Nepal suggest that planted pine forest has a greater evapotranspiration rate than natural forest or degraded land and that this could be the reason for drying water resources in the middle hills in Nepal (Baral 2011). VACA results suggested that availability of water for household use is still sufficient to meet demand, but not for agriculture. Of 385 respondents, 257 households have sufficient water for agriculture for less than 6 months in a year. Figure 5 provides details on perceived water availability for agriculture in a year.

\subsection{Local institutions and governance}

Success of ecosystem management in developing countries is dependent on sound governance structures at various levels, in particular at the local level. Good Governance is discussed by many scholars as central to successful adaptation. Cannon and Muüller-Mahn (2010) used the term 'adaptive governance', which they considered part of institutional planning and argued for the need of critical assessment. Ribo (2011) considered good government is important and governing requires checks and balances. The checks and balances come from synergy and collaborative efforts while supporting government 
Table 3. Major forest products for community livelihoods and their changing trend on availability.

\begin{tabular}{|c|c|c|}
\hline $\begin{array}{l}\text { Major forest products } \\
\text { (Ecosystem goods) }\end{array}$ & Average use pattern per household & Change trend on availability \\
\hline $\begin{array}{l}\text { Timber for house } \\
\text { construction }\end{array}$ & $\begin{array}{l}\text { As per requirement (once at the time of house construction). However, } \\
\text { there is limited timber available in Community Forests (CF). }\end{array}$ & Stable \\
\hline Timber of other use & $\begin{array}{l}\text { As per requirement, need to pay royalty to Community Forest User Group } \\
\text { committee (CFUG). }\end{array}$ & Stable \\
\hline Fuelwood & $\begin{array}{l}\text { CF opens twice a year, normally at the time of pruning, thinning for } \\
\text { fuelwood collection. }\end{array}$ & Stable \\
\hline Leaf litters (3) & $\begin{array}{l}\text { CF opens } 1-2 \text { times per year for } 1 \text { month. Leaf litter is also supplied from } \\
\text { private land. }\end{array}$ & Slightly declining \\
\hline $\begin{array}{l}\text { Pine needles, leaf litter } \\
\text { for compost }\end{array}$ & As part of leaf litter. & Slightly declining \\
\hline $\begin{array}{l}\text { Ningalo (Arundinaria } \\
\text { species) }\end{array}$ & $\begin{array}{l}\text { Limited Ningalo (Arundinaria species) available in CF, mostly in private } \\
\text { land. }\end{array}$ & Heavily declining \\
\hline $\begin{array}{l}\text { Medicinal and } \\
\text { aromatic plants }\end{array}$ & Many species of medicinal and aromatic plants available. & $\begin{array}{l}\text { Some species such as Nagbeli } \\
\text { (Lycopodium clavatum) } \\
\text { declining }\end{array}$ \\
\hline Grass/fodder & $\begin{array}{l}\text { Oak is primary fodder species supplying major fodder for livestock in the } \\
\text { area. Kutmiro (Litsea poliantha Dudhilo (Ficus nemoralis) are available } \\
\text { in private land. }\end{array}$ & Declining \\
\hline $\begin{array}{l}\text { Lokta (Daphne } \\
\quad \text { species) }\end{array}$ & $\begin{array}{l}\text { Two species available. Major source of income of poor households. Raw } \\
\text { material for Nepali Handmade paper. }\end{array}$ & Sikre (Daphne bhaula) declining \\
\hline
\end{tabular}

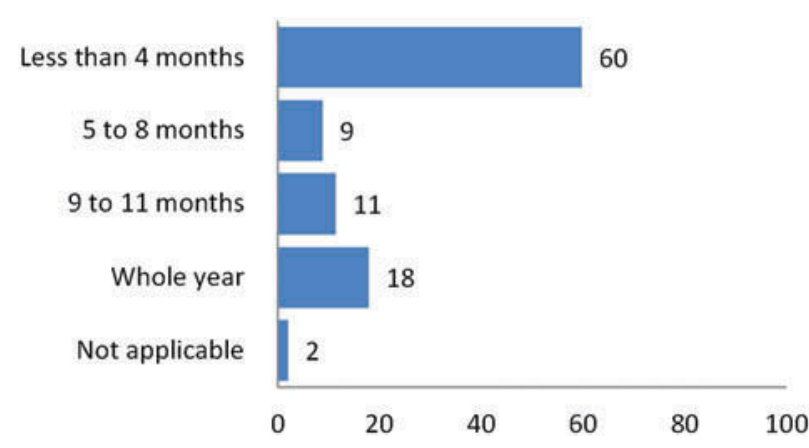

Figure 5. Perceived water sufficiency for agriculture use during the last 12 months (in \%).

actions by various actors collectively rather than working in isolation (IPCC 2007b). Nepal's national adaptation plan of action identified six thematic areas of urgent focus to address issue of climate change while emphasising the need for an integrated approach between the various actors and economic sub-sectors. However, both vertical and horizontal coordination is often an issue while implementing at the local level (Gentle \& Maraseni 2012; Ojha 2013; Bhatta et al. 2014). Focus group discussants also highlighted the need for synergy and collaboration among various institutions working in the areas for collective action to achieve concrete outcomes for local livelihoods in adapting to climate change and other forms of changes.

There are number of institutions providing services to the communities in the research area, for example, village development committees (VDCs), Community forest user groups (CFUGs), water management groups, saving and credit groups, and the agriculture service centre. CFUGs are considered to be very important institutions as they are mandated to manage local forest resources. VDCs are also important institutions in providing services in managing ecosystem services and providing support for local adaptation strategies. However, participants of focus group discussions and also the key informant survey suggest that VDC plans are mostly focusing on infrastructure development. The district plans also fail in providing local adaptations in managing ecosystem services. Implementations of the activities from district line agencies, such as soil conservation, are in isolation from rather than being part of coherent and collective planning. There is a strong need for integrated planning and long-term capacity development of stakeholders at the local level to cope with recent environmental challenges.

\subsection{Major adaptation practices}

Global discussions on climate change are shifting from an emphasis on vulnerability (Orlove \& O'Brien 2009), and active adaptation has now become central to the global climate change debate (Dovers 2009). Adaptation is now discussed as enabling communities to cope and improve livelihoods in the light of climate stress and shocks (Agrawal 2009; Orlove \& O'Brien 2009). Local communities have been practising various adaptation measures based on their immediate needs. Some times this has been referred to as unplanned or autonomous adaptation. However, greater adaptive planning is needed to increase the capacity of communities to cope with decreased water availability, crop failure, and the resulting decrease in food production.

Focus group discussions suggested that communities are concerned with the immediate and short term, as well as in developing long-term coping strategies. Their ability 
to adopt these strategies is mostly based on their ability in terms of economy and external support form society and other actors. Examples of short-term solutions during times of scarcity include selling of household property and livestock, reduced spending on clothes, consuming seed stocks, and looking for labouring jobs in other villages (Figure 6). Also rainwater harvesting has been introduced by some of the households. A majority of households borrowed money as a loan and considered this as a short-term and immediate strategy to deal with crop failure and scarcity.

Major long-term adaptation strategies (Figure 7) were found especially in the relatively wealthy households who owned land for agriculture, but some changes of practices appear to be independent of the state of the economy. Long-term solutions indicated by households included exploring improved varieties of seed, use of different agriculture practices requiring less water, and giving up growing some crops which require more water. Sustainable management of these ecosystem services must be introduced to secure sustainable rural livelihoods and to avoid further unsustainable water- and land use and soil depletion. Additionally, some of those who can afford

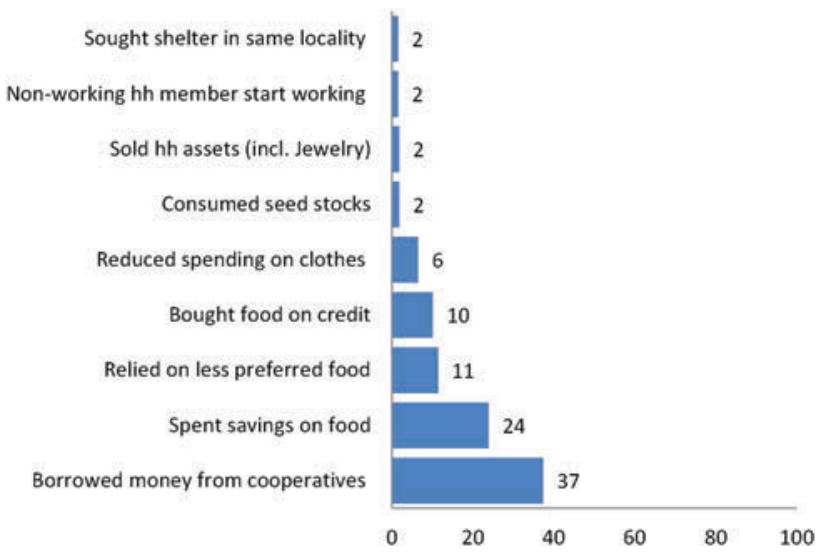

Figure 6. Major coping mechanisms to deal with changes over 2003-2013 (in \%).

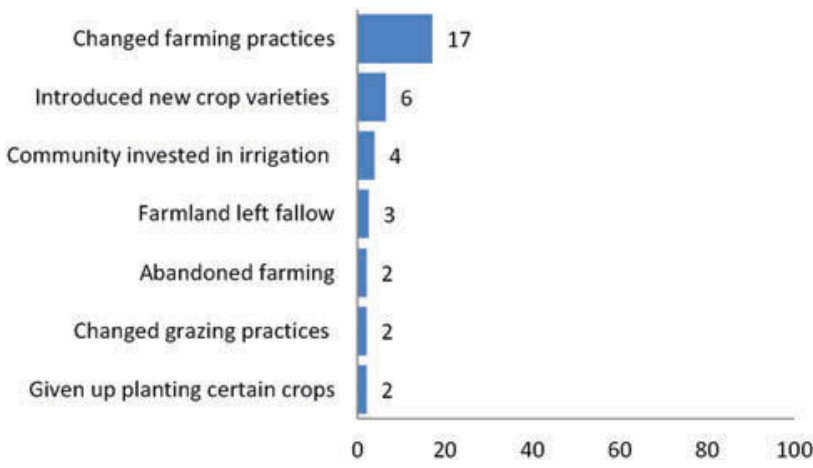

Figure 7. Major adaptive strategies to deal with changes observed over 2003-2013 (in \%). it have started to make investments in small-scale irrigation schemes.

\section{Conclusions}

Community perceptions and experiences, supported by meteorological data, reveal that changing climate is negatively impacting on the provision of various ecosystem services and the livelihoods of local communities in the research area. Erratic rainfall, snowfall, and prolonged drought are the major climatic hazards which pose greatest risk on agricultural production, the major source of livelihoods. Additionally, forest products, in particular commercial nontimber forest products, and livestock rearing, particularly sheep and Himalayan goat, are also under threat. These threats and risks increase the vulnerability of low income farmers, in particular those who do not have the capacity for short- to long-term adaptation. Water, particularly for agricultural use, has become a scarce resource and often more so at some times of the year. With the observed drying up of natural springs, water availability has reduced substantially, forcing farmers to either change their agricultural practices or abandon agriculture.

Farmers have been practising a range of both shortterm and long-term strategies to deal with climate change impacts. The strategies cover both immediate and reactive solutions motivated by an imminent crisis (coping) as well as adaptation strategies, which involved planning and are part of a more continuous process. The majority of farmers have borrowed money to cope. However, access to loans is limited and there is a need to diversify available financial services. Shifting agriculture practices from cereal crops to vegetables and introducing new varieties of agriculture crops are other major long-term adaptive strategies. We suggest that investigations of more drought-tolerant varieties of crops might be a useful alternative adaptive strategy rather than the introduction of new exotic varieties of agricultural crops. The increasing impact of invasive weeds and insect pest species, in particular in reducing natural regeneration of forest crops, is a major threat to the supply of forest products. The degree of the impact of these species, however, needs further investigation.

Adapting to climate change is not just a technical issue and cannot be addressed in the same way as some dimensions of development and governance. We suggest climate adaptation needs to be considered in a wider context within the development dimension rather than in isolation. To increase the adaptive capacity of poor households, we suggest incorporating climate change adaptations within the local planning process. Additionally, local development infrastructures play a crucial role in increasing the adaptive capacities of communities, and local governments can play crucial role in developing such infrastructures. The development dimension of climate change adaptation should focus on (1) increased provision of agriculture services, including access to financial institution, (2) crop and livestock insurance could be viable options to limit the 
impact of crop failures resulting from climate change, (3) securing land tenure and increased access to livelihood resources, including forest resources, and finally, (4) strengthening the capacity of local governments such as VDC, DDC and associated local institutions to reduce the vulnerability and increase the adaptive capacity of local communities.

\section{Acknowledgements}

The views and interpretations in this publication are those of the author(s). We thank Nand K. Agrawal, Programme Coordinator of ICIMOD/HICAP, for his valuable support during this study. We also thank Ieva Rucevska and Bijan Devnath for their support in producing high resolution figure and Anju Pandit for her support on typography. Thanks are also due to two anonymous reviewers and the Associate Editor for comments that helped improve the manuscript.

\section{Disclosure statement}

No potential conflict of interest was reported by the authors.

\section{Funding}

This study was a part of the Himalayan Climate Change Adaptation Programme (HICAP). HICAP is implemented jointly by ICIMOD, CICERO, and UNEP/Grid-Arendal in collaboration with local partners and is funded by the Ministry of Foreign Affairs, Norway, and Swedish International Development Agency (SIDA).

\section{References}

Adger WN, Huq S, Brown K, Conway D, Hulme M. 2003. Adaptation to climate change in the developing world. Prog Dev Stud. 3:179-195.

Agrawal A. 2009. Local institutions and adaptation to climate change. In: Mearns R, Norton A, editors. Social dimensions of climate change: equity and vulnerability in a warming world. Washington (DC): The World Bank; p. 173-198.

Agrawal A, Perrin N. 2008. Climate adaptation, local institutions and rural livelihoods. IFRI Working Paper, Wo8I- 6. Ann Arbor: International Forestry Resources and Institutions Program; University of Michigan.

Alexander KS, Millar J, Lipscombe N. 2010. Sustainable development in the uplands of Lao PDR. Sust Dev. 18:62-70.

Baral H. 2013. Ecosystem goods and services in production landscapes in south-eastern Australia [dissertation] Melbourne: Melbourne School of Land and Environment, The University of Melbourne.

Baral H, Keenan RJ, Sharma SK, Stork NE, Kasel S. 2014. Economic evaluation of ecosystem goods and services under different landscape management scenarios. Land Use Policy. 39:54-64.

Baral H, Keenan RJ, Stork NE, Kasel S. 2014. Measuring and managing ecosystem goods and services in changing landscapes: a south-east Australian perspective. J Environ Plann Manag. 57:961-983.

Baral TR. 2011. Evapotranspiration from natural and planted forest in the middle mountains of Nepal [dissertation]. Enschede: University of Twente.

Berrang-Ford L, Ford JD, Paterson J. 2011. Are we adapting to climate change? Global Environ Chang. 21:25-33.
Bhatta LD, van Oort BEH, Rucevska I, Baral H. 2014. Payment for ecosystem services: possible instrument for managing ecosystem services in Nepal. Int J Biodivers Sci Ecosyst Serv Manag. November:1-11.

Boon E, Ahenkan A. 2012. Assessing climate change impacts on ecosystem services and livelihoods in Ghana: case study of communities around Sui Forest Reserve. J Ecosyst Ecogr. S3:1.

Boyd J, Banzhaf S. 2007. What are ecosystem services? The need for standardized environmental accounting units. Ecol Econ. 63:616-626.

Cannon T, Muüller-Mahn D. 2010. Vulnerability, resilience and development discourses in context of climate change. Nat Hazards. 55:621-635. doi:10.1007/s11069010-9499-4

Carney D. 1998. Implementing the sustainable rural livelihoods approach. Chapter 1. In: Carney D, editor. Sustainable rural livelihoods: what contribution can we make? London (UK): Department for International Development.

CBS Nepal. 2011. Environment statistics of Nepal 2011. Kathmandu: Central Bureau of Statistics; p. 200.

Chambers R. 1994. The origins and practice of participatory rural appraisal. World Dev. 22:953-969.

Chambers R, Conway G. 1992. Sustainable rural livelihoods: practical concepts for the 21 st century. IDS Discussion Paper 296. Brighton (UK): Institute of Development Studies.

Charmakar S. 2010. Exploring existing local adaptation practices and potential strategic options to address climate change impact on biodiversity and its dependents of Nepal, Report submitted to National Adaptation Programme of Action/ Ministry of Environment. Kathmandu: Government of Nepal.

DFO. 2012. Annual Progress Report 2012. Dolakha: District Forest Office.

Dovers S. 2009. Normalizing adaptation. Global Environ Chang. 19:4-6.

Ellis F. 2000. Rural livelihoods and diversity in developing countries. Oxford (UK): Oxford University Press.

FAO. 1999. Forest resources of Nepal - Country report [Internet]. Rome; p. 78. [cited 2014 Aug 12]. Available from: ftp://ftp. fao.org/docrep/fao/007/ae154e.

Fisher B, Turner RK. 2008. Ecosystem services: classification for valuation. Biol Cons. 141:1167-1169.

Fisher B, Turner RK, Morling P. 2009. Defining and classifying ecosystem services for decision making. Ecol Econ. 68:643-653.

Gentle P, Maraseni TN. 2012. Climate change, poverty and livelihoods: adaptation practices by rural mountain communities in Nepal. Environ Sci Policy. 21:24-34.

Hahn MB, Riederer AM, Foster SO. 2009. The livelihood vulnerability index: a pragmatic approach to assessing risks from climate variability and change-A case study in Mozambique. Global Environ Chang. 19:74-88.

Holmelin N, Aase TH. 2013. Flexibility of scope, type and temporality in mustang, Nepal. Opportunities for adaptation in a farming system facing climatic and market uncertainty. Sustainability. 5:1387-1405.

ICIMOD. 2010. Climate change impact and vulnerability in the eastern Himalayas - Synthesis report. Kathmandu: International Centre for Integrated Mountain Development.

Intergovernmental Panel on Climate Change (IPCC). 2001. Climate change 2001: impacts, adaptation and vulnerability. Cambridge (UK): Cambridge University Press.

Intergovernmental Panel on Climate Change (IPCC). 2007a. Summary for policy makers. In: Parry ML, Canziani OF, Palutikof JP, Linden PJ, Hanson CE, editors. Climate change 2007: impacts, adaptation and vulnerability. Contribution of Working Group II to the fourth assessment report of the intergovernmental panel on climate change. Cambridge (UK): Cambridge University Press; p. 1-18. 
Intergovernmental Panel on Climate Change (IPCC). 2007b. Assessment of adaptation practices, options, constraints and capacity. Cambridge (UK): Cambridge University Press.

Macchi M, Gurung AM, Hoermann B, Choudhury D. 2011. Climate variability and change in the Himalayas: community perceptions and responses. Kathmandu: International Centre for Integrated Mountain Development (ICIMOD).

Marshall N, Marshall P, Tamelander J, Obura D, Malleret-King D, Cinner J. 2009. A framework for social adaptation to climate change: sustaining tropical coastal communities and industries. Switzerland: IUCN; p. v +36 .

Millennium Ecosystem Assessment. 2005. Ecosystems and human well-being: synthesis. Washington (DC): Island Press.

Ministry of Environment. 2010. National Adaptation Programme of Action (NAPA). Kathmandu: Ministry of Environment.

Niraula RR, Gilani H, Pokharel BK, Qamer FM. 2013. Measuring impacts of community forestry program through repeat photography and satellite remote sensing in the Dolakha district of Nepal. J Environ Manage. 126:20-29.

Ojha H. 2013. Misplaced adaptation. Kantipur daily Vernacular [Internet]. [cited 2013 Sep 18]. Available from: http://www. ekantipur.com/2013/03/05/top-story/misplaced-adaptation/ 367979.html

Orlove B. 2009. The past, the present and some possible futures of adaptation. In: Adger WN, Lorenzoni I, O'Brien K, editors. Adapting to Climate Change: thresholds, Values, Governance. Cambridge (UK): Cambridge University Press; p. 131-163.

Pasteur K. 2010. From vulnerability to resilience: a framework for analysis and action to build community resilience. Rugby (UK): Practical Action.

Paudel P. 2013. Climate change vulnerability of mountain agriculture: a case from Sushma Chhemawati VC, Dolakha district [dissertation]. Kathmandu: Tribhuvan University.

Paudyal K, Baral H, Burkhard B, Bhandari SP, Keenan RJ. 2015. Participatory assessment and mapping of ecosystem services in a data-poor region: case study of community-managed forests in central Nepal. Ecosyst Serv.

Practical Action. 2009. Temporal and spatial variability of climate change over Nepal (1976-2005). Kathmandu (Nepal): Practical Action.

Regmi HR. 2007. Effect of unusual weather on cereal crops production and household food security. J Food Agri Environ. 8:20-29.

Ribo J. 2011. Vulnerability before adaptation: toward transformative climate action. Global Environ Chang. 21:1160-1162.

Scoones I. 1998. Sustainable rural livelihoods: a framework for analysis. IDS Working Paper 72. Brighton (UK): Institute of Development Studies.

Shrestha UB, Gautam S, Bawa KS. 2012. Widespread climate change in the Himalayas and associated changes in local ecosystems. PLoS One. 7:e36741.

Smit B, Burton I, Klein RJT, Wandel J. 2000. An anatomy of adaptation to climate change and variability. Clim Chang. 45:223-251.

TEEB. 2009. TEEB for national and international policy makers. Summary: responding to the value of nature. Geneva: UNEP.

UNDP. 2004. Reducing disaster risk: a challenge for development [Internet]. Geneva. [cited 2013 Aug 15]. Available from: http://www.undp.org/cpr/whats new/rdr english.pdf

van de Sand I. 2012. Payments for ecosystem services in the context of adaptation to climate change. Ecol Soc. 17:11.

van Oort B, Bhatta LD, Baral H, Rai RK, Dhakal M, Rucevska I, Adhikari R. 2014. Assessing community values to support mapping of ecosystem services in the Koshi river basin, Nepal. Ecosyst Serv.

Wallace K. 2007. Classification of ecosystem services: problems and solutions. Biol Cons. 139:235-246.

Xu J, Shrestha A, Vaidya R, Eriksson M, Hewitt K. 2007. The melting Himalayas: regional challenges and local impacts of climate change on mountain ecosystems and livelihoods. Kathmandu: ICIMOD. 